\title{
Prinsip dalam keperawatan jiwa
}

Novrial Ahmad Hanif / Ahmadnovrial15@gmail.com

Latar belakang

Abstract: Mental health is projected to be one of issues that would be a problem among people's live in the future. This issue is caused by a lack of knowledge and insight into the mental health community, as well as the negative stigma attached to people's perceptions of mental illness and the sufferers. The negative stigma hamper government and community efforts in creating mental health in the community. Stigma obstruct the recovery process of mental disorders that can happen to any human being and for the sufferers will be difficult to live in the midst of the general public. "balai kesehatan jiwa" that is designed aiming at providing a forum for people with mental disorders transition before returning to the life of society, as well as to create containers mental health services closer to the people so that the people who sought mental health can be achieved more efficiently.the concept of environment's design is applied using a basic principle as the basis of healing environmental considerations whole aspects both component architecture and components forming other neighborhoods that are conducive and supportive user's mental health. This building is planned by the location, building appearance, structure, landscaping and utilities on the building considering the stimulants wich is received by the users from the building components.

Keywords: Negative Stigma, Mental Health Centre, Containers Transition, Healing Environmen

\section{PENDAHULUAN}

Stigma negatif tentang gangguan jiwa merupakan permasalahan utama yang melatarbelakangi ide perencanaan dan perancangan balai kesehatan jiwa tersebut. Stigma negatif yang sudah melekat pada persepsi setiap orang memiliki dampak negatif bagi orang lain bahkan dirinya sendiri. Stigma negatif bahwa gangguan jiwa akan menyebabkan orang bertindak kekerasan, tidak dapat disembuhkan dan menjadi aib bagi seseorang telah menjadi masalah serius ditengah-tengah masyarakat. Adanya stigma negatif ini diperburuk dengan perilaku dari masyarakat yang seolah-olah membenarkan stigma tersebut. Akibatnya, banyak kasus pemasungan, stres, halusinasi, dan kasus kesehatan jiwa lainnya yang semakin parah akibat penanganan yang terlambat atau kurang tepat karena kurangnya pengetahuan dan wawasan masyarakat. Adanya stigma 
ini mempersulit hubungan antara masyarakat umum dengan penderita gangguan jiwa yang juga menginginkan kehidupannya kembali, sehingga masalah dari stigma negatif tersebut menyebar menjadi permasalahan banyaknya gelandangan psikosis di kota-kota di Indonesia (depkes.go.id). Balai kesehatan jiwa yang direncanakan bertujuan untuk memberikan wadah transisi bagi penderita gangguan jiwa sebelum dapat benar-benar kembali ke tengahtengah masyarakat. Para penderita ini diberdayakan dan diberi bekal untuk hidup di masyarakat sebagai mantan penderita gangguan jiwa. Selain itu, balai kesehatan jiwa ini juga menyediakan pelayanan kesehatan jiwa bagi masyarakat umum. Sejauh ini, masyarakat umum mengetahui pelayanan kesehatan jiwa hanya pada rumah sakit jiwa, dan tempat-tempat praktek psikiatri yang tidak banyak diketahui oleh masyarakat itu sendiri. Gangguan jiwa dapat menyerang siapa saja, karena pada dasarnya setiap manusia memiliki perbedaan faktor psikologis dimana pada titik tertentudapat dikatakan mengalami gangguan atau abnormal (Eko Prabowo, 2014). Menanggapi masalah -masalah tersebut, balai kesehatan jiwa yang dirancang ini berupaya untuk mendekatkan dan memberi wadah bagi masyarakat umum dan penderita gangguan jiwa untuk mendapatkan pelayanan kesehatan jiwa serta berinteraksi dengan tujuan pengurangan dan menghilangkan stigma negatif yang melekat diantara kedua belah pihak. Healing Environmentdigunakan sebagai metode pendekatan pada perancangan balai kesehatan jiwa ini. Prinsip-prinsip pada Healing Environmentdinilai cocok sebagai kriteria keputusan desain yang diambil pada perancangan lingkungan yang direncanakan. Lingkungan menjadi salah satu faktor yang sangat berperan dalam proses penyembuhan dan penciptaan kesehatan jiwa masyarakat. Desain pada lingkungan di sekitar sangat mempengaruhi tingkat kesembuhan pengguna. Pola Perilaku penggunajuga dipengaruhi oleh rangsangan-rangsangan diterima dari lingkungan (Joyce Marcella Laurens, 2004). Beberapa kasus telah membuktikan bahwa pasien gangguan jiwa kembali kambuh setelah dipulangkan kerumahnya karena kondisi lingkungan rumahnya dianggap tidak kondusif dan justru memberikan rangsangan buruk. Untuk mendukung upaya penciptaan kesehatan jiwa dan kesejahteraan hidup masyarakat, Healing Environment diterapkan guna menciptakan lingkungan yang kondusif dan supportive bagi kesehatan jiwa manusia.

\section{METODE}

Pada dasarnya, Healing Environment menitik beratkan pada metode perancangan seluruh aspek pada komponen arsitektur terutama komponen-komponen pembentuk lingkungan. Selain komponen pembentuk lingkungan ini yang nantinya akan berinteraksi langsung dengan pengguna melalui panca indera. Komponen-komponen tersebut antara lain adalah: 1. Peruangan 2. Lokasi 3. Komponen pembentuk lingkungan: a. Warna. b. View. c. Bentuk. d. Tekstur. e. Pencahayaan. f. 
Suara. g. Termal. h. Aroma. Komponen -komponen pembentuk lingkungan tersebut memiliki berbagai jenis dan macamnya. Pemilihan jenis dari berbagai macam komponenkomponen desain tersebut didasarkan atas kriteria yang digunakan sesuai dengan prinsip Healing Environmentuntuk perancangan wadah pelayanan kesehatan jiwa. Prinsip Healing Environmentyang digunakan mengalami pengembangan yaitu merujuk pada prinsip-prinsip Healing Environmentuntuk fasilitas kesehatan jiwa. Pengembangan khusus ini bertujuan untuk mendapatkan kriteria perancangan yang lebih spesifik dan sesuai dalam perancangan lingkungan yang memulihkan dan menciptakan suatu kesehatan khususnya kesehatan mental atau jiwa penggunanya. (Ralene van der Walt and Ida Breed, 2012). Prinsip-prinsip tersebut antara lain adalah:

\section{Stimulant (rangsangan)}

2.Coherence (kesinambungan)

3.Affordance (keberhasilan)

4.Independence(kebebasan/kelelua saan)

5.Consciousness (kesadaran)

6.Purpose (kujuan)

7.Physical Activities (kegiatan kisik)

\section{Restorative (pemulihan)}

Prinsip-prinsip tersebut digunakan dan diterapkan dalam proses analisis setiap komponen perancangan balai kesehatan jiwa yang direncanakan. Arsitektur memiliki peran penting dalam kesehatan jiwa manusia, karena arsitektur merupakan ilmu perancangan lingkungan yang menjadi wadah bagi manusia menciptakan kesehatan tersebut (Gary W. Evans And Janetta Mitchell Mccoy, 1998).

\section{HASIL PENELITIAN}

Dari hasil analisa data didapatkan bahwa ada lima tujuan yang ingin dicapai perawat dalam memberikan asuhan keperawatan kepada pasien, yaitu: Memperbaiki wawasan dan pemahaman pasien Memperbaikit wawasan dan pemahaman pasien menjadi fokus perawat dalam pelayanan kesehatan jiwa di RSJ Banda Aceh. Memahami masalah sesuai dengan perspektif pasien dapat dilakukan dengan mendengar aktif dan tidak mendominasi pasien dalam komunikasi. Hal ini tergambar dari beberapa ucapan perserta wawancara sebagai berikut: "Saya berusaha mendengarkan..., ...kemudian mencoba berdiskusi... Dalam diskusi dengan pasien, perawat harus mencoba memperbaiki wawasan dan pemahaman pasien tentang penyakitnya...". Diskusi yang dilakukan perawat dengan pasien harus mampu menemukan masalah yang dialami pasien dan bagaimana masalah tersebut menekan psikologisnya. Namun diskusi yang dilakukan untuk memperbaiki wawasan dan pengetahuan pasien selama ini masih fokus pada mengatasi dan mengontrol tujuh keluhan utama gangguan jiwa. Dalam meningkatkan wawasan dan pengetahuan, perawat harus menggunakan bahasa yang mudah dimengerti, dan bila perlu langsung 
dipraktekkan.

Meningkatkan

kemandirian pasien Peningkatan

kemandirian pasien juga merupakan tujuan perawat dalam pelaksanaan asuhan keperawatan. Pemenuhan kebutuhan, motivasi dan pemberian tanggung jawab dianggap mampu meningkatkan kemandirian pasien. Namun kegiatan ini harus dilakukan sesuai perkembangan pasien. Hal dapat dilihat dari beberapa pernyataan perawat dalam wawancara kelompok fokus sebagai berikut: "Adalah penting untuk meningkatkan kemandirian pasien,..., ... untuk menjadi mandiri, perawat harus memberi motivasi, memenuhi kebutuhan, memberi tanggung jawab, memberi latihan..., ... Meningkatkan kemandirian pasien harus disesuaikan dengan perkembangan dan kemampuan pasien..., Menurut perawat, kemandirian pasien sangat berkaitan dengan wawasan dan pengetahuan mereka tentang penyakitnya. Perawat harus mengajarkan, melatih dan melibatkan pasien dalam aktivitas perawatan. Meningkatkan kemandirian pasien harus dilakukan dengan memberi tanggung jawab melakukan tindakan perawatan dan pengobatan. Pasien harus terus dimotivasi melakukan kegiatan secara mandiri, tanpa tergantung pada perawat ruangan. Evaluasi penting untuk menjamin tingkat kemandirin pasien terus berkembang setiap harinya. Meningkatkan kerja sama dengan keluarga pasien Perawat yakin bahwa keterlibatan keluarga dalam perawatan pasien di rumah sakit sangat penting bagi perkembangan pasien. Selain itu, keterlibatan keluarga dapat memperbaikit wawasan dan pengetahuan mereka dalam merawat pasien di rumah. Hal ini dapat dilihat dari beberapa pernyataan perawat dalam wawancara kelompok fokus sebagai berikut: "Kita harus melibatkan keluarga dalam perawatan dan pengobatan ..., perkembangan pasien akan lebih cepat, kalau keluarga terlibat.......keluarga akan memperoleh pengetahuan penting yang dapat digunakan untuk merawat pasien di rumah, ...". Menurut perawat kerjasama dengan keluarga diarahkan pada peningkatan pengetahuan, kesadaran dan kemaun keluarga untuk mendukung perawatan dan pengoabatan pasien di rumah sakit dan perawatan pasien di rumah. Hal ini penting karena keluarga memiliki arti dan pengaruh dalam proses kesembuhan pasien. Keluarga harus memahami bagaimana merawat pasien dengan baik, tanpa memprovokasi perasaan mereka. Meningkatkan kerja saman antar profesi Kerjasama lintas profesi sangat penting dalam upaya meningkatkan kualitas pelayanan. Semua profesi yang terlibat dalam perawatan dan pengobatan pasien harus mampu bersinergi sesui dengan peran dan fungsinya masing-masing sehingga praktek pelayanan menjadi lebih baik. Hal ini telihat dari salah satu pernyataan perawatan dalam wawancara kelompok fokus sebagai berikut: "Kita harus memperkuat kerja sama antara perawat dan kelompok profesi lain, seperti dokter, psikiater, dan psikolog untuk memperbaiki praktek". Permasalahan yang dihadapi dalam peningkatan kerjasama lintas profesi adalah tingginya ego sektoral masing-masing profesi tentang peran 
dan tanggung jawab mereka. Memperbaiki praktek pelayanan Keinginan perawat memperbaikit kualitas pelayanan di RSJ Banda Aceh sangat besar. Untuk meningkatkan kualitas pelayanan, perawat menginginkan adanya sistem reward and punsihment yang jelas. Selain itu, perawat harus diberi kebebasan dan dukungan dalam mengembangkan kualitas pelayanan. Menyediakan apa yang dibutuhkan perawat dalam memberikan pelayanan adalah salah satu wujud dukungan yang diinginkan perawat. Hal ini dapat dilihat dari beberapa :pernyataan peserta wawancara kelompok fokus sebagai berikut: "Saya menginginkan situasi kerja yang nyaman dan pasien dapat dirawat dengan cara yang lebih bagus,...dengan memberikan apa yang dibutuhkan perawat ..., ... perawat akan lebih fokus pada upaya perbaikan praktek, ...". Perawat menginginkan adanya kombinasi Model Praktek Keperawatan Profesional (MPKP) dengan terapi lingkungan dalam meningkatkan kualitas pelayanan. Hal dapat dimulai dengan penyusunan Standar Operasional Prosedur (SOP) sebagai pedoman.

\section{PEMBAHASAN}

Tujuan pelayanan kesehatan jiwa Merupakan batasan yang ingin dicapai dalam bekerja dengan pasien. Departemen dapat menilai kinerja petugas dan unit kerja melalui pencapaian tujuan yang telah ditetapkan (Helsekompetanse, 2010). Tujuan menjadi landasan utama pengembangan layanan kesehatan jiwa. Dalam penelitian ini teridentifikasi lima tujuan yang ingin dicapai perawat di RSJ Banda Aceh dalam memberikan asuhan keperawatan jiwa, yaitu meningkatkan wawasan dan pemahaman pasien, meningkatkan kemandirian pasien, meningkatkan kerjasama dengan keluarga pasien, meningkatkan kerjasama lintas profesi, dan memperbaikit praktek atau kualitas layanan. Sedangkan tujuan yang didapatkan pada penelitian serupa di Rumah Sakit Innlandet Norwegia, yaitu: meminimalkan gejala, meningkatkan kemampuan dalam perawatan diri, mengembangkan kompetensi khusus dalam keperawatan, pengobatan dan rehabilitasi, menyediakan lingkungan yang positif bagi pasien dengan perawatan dan pengobatan jangka panjang, dan mengembangkan terapi lingkungan yang menjamin keterlibatan pasien (Nysveen et al., 2008; Bond \& Campbell, 2008). Hal ini menunjukkan bahwa tujuan perawatan di RSJ Banda Aceh masih fokus pada penanganan gejala gangguan jiwa, belum mengarah pada modivikasi lingkungan dan rehabilitasi. Salah satu tujuan yang diungkapkan perawat dalam waancara kelompok fokus adalah peningkatan wawasan dan pemahaman pasien. Saat ini, peningkatan wawasan dan pemahamam pasien masih fokus pada tujuh gejala utama penyakit jiwa, yaitu depresi, waham, halusinasi, isolasi sosial, harga diri rendah, prilaku kekerasan, dan prilaku bunuh diri. Hal ini merupakan perwujudan dari pelaksanaan Model Praktik Keperawatan Profesional (MPKP) jiwa yang dikembangkan paska tsunami, dimana tindakan perawatan diarahkan 
pada pengontrolan gejal-gejala tersebut. Sementara tindakan rehabilitasi sosial dan penyediaan lingkungan positif yang memberi kesempatan pasien bangkit dari trauma masa lalu melalui penguatan sistem koping dan kemampuan menghadapi dan menyelesaikan masalah hidup belum banyak diperhatikan. Ketidakmampuan menghadapi masalah sering menjadi kendala ketika pasien kembali ke keluarga dan masyarakat. Stigmatisasi dan diskriminasi merupakan masalah klasik yang dihadapi pasien. Stigmatisasi dan diskriminasi sering menjadi stresor pemicu kekambuhan. Oleh karen itu, keterampilan pasien menghadapi dan menyelesaikan masalah dalam kehidupan juga perlu mendapat perhatian disamping penyakit itu sendiri. Hal ini telah lama disampaikan Antonovsky bahwa seseorang yang memiliki pengalaman yang baik dalam proses penyelesaian masalah memiliki jiwa yang lebih sehat (Almvik og Borge, 2006). Peningkatan kemampuan menyelesaikan konflik atau masalah dapat dilakukan dengan mangajarkan pasien memahami sistuasi (pemahaman), kemudian diyakinkan bahwa pasien memiliki sumber daya penting dalam penyelesaian masalah (pengelolaan), dan merasakan bahwa tantangan yang dihadapi merupakan sebuah sumber motivasi (kegunaan) (Almvik og Borge, 2006). Ketika pasien memahami situasi, pasien dapat memutuskan menyelesaikan sendiri masalahnya atau mencari dukungan orang lain.. Supaya perawat sukses meningkatkan wawasan dan pemahaman pasien terhadap penyelesaian masalah.
Hummelvoll, (2008) menganjurkan perawat mengali informasi tentang bagaiman pasien merasakan dan memahami situasi yang menyebabkan stres, bagaimana sikap dan kepercayaannya terhadap kemampuan menyelesaikan masalah, dan apa yang harus dilakukan untuk mengembangkan kemampuan penyelesaian masalah. Informasi ini sangat penting dalam mengembangkan lingkungan yang memungkinkan pasien belajar memahami dan menghadapi msalah, bukan lari dari permaslahan atau menstigma diri bahwa permasalahannya tidak bisa diselesaikan. Tujuan kedua yang dianggap penting oleh perawat adalah peningkatan kemandirian pasien. Pendekatan terapi lingkungan mendasarkan tindakan perawatan dan pengobatan pada peningkatan autonomi dalam upaya pemberdayaan pasien (Schjødt og Heinskou, 2007). Pasien perlu diberikan tanggung jawab dalam melaksanakan kegiatan harian di rumah sakit. Menyelesaikan tanggung jawab yang diberikan dapat mengaktifkan kembali potensi dan sumber daya pasien. Pengalaman positif yang diperoleh pasien saat melaksanakan tanggung jawab dapat meningkatkan harga diri dan kepercayaan diri pasien. Perawat dalam wawancara kelopok fokus mengatakan bahwa meningkatkan autonomi bisa dilakukan dengan memenuhi kebutuhan, memotivasi, memberi tanggung jawab dan memberi latihan sesuai dengan perkembangan pasien. Pender, Murdaugh \& Pasons (2010) mengatakan bahwa pengetahuan 
berbasis pengalaman merupakan intervensi yang efektif dalam memberdayakan pasien (empowerment). Pengalaman positif dapat meningkatkan kepercayaan dan keyakinan pasien dalam mengatasi masalah. Keyakinan akan memberikan kekuatan pada pasien untuk terus belajar menyelesaikan masalah yang dihadapi. Setiap keberhasilan menyelesaikan masalah akan menjadi potensi dan kekuatan pasien dalam menyelesaikan permasalah yang dihadapi di masa yang akan datang, sehingga pasien lebih mandiri dalam menghadapi permasalah yang dihadapi. Berdasarkan perspektif empowerment, perawat tidak memiliki kontrol penuh terhadap pasien. Perawat hanya berfungsi sebagai fasilitator dalam pengambilan keputusan (Eplov, Peterson, dan Olander, 2010). Perawat tidak boleh memaksakan pengetahuan dan pengalaman yang dimiliki sebagai solusi bagi permasalahan pasien. Dalam banyak kasus, tindakan yang tidak didiskusikan atau tidak disetujui pasien sering menjadi stresor sehingga meningkatkan ketegangan pasien yang pada akhirnya dapat menjadi faktor presipitasi terhadap kekambuhan pasien. Perbedaan persepsi tentang pemberian autonomi terjadi dalam wawancara kelompok fokus dan pengajaran berbasis dialog. Sebagian perawat belum yakin bahwa autonomi bisa diberikan pada pasien dengan psikosis, apalagi mengajak mereka terlibat dalam menentukan bentuk dan arah perawatan serta pengobatan. Perawat cendrung melaksanakan tindakan perawatan dan pengobatan yang mereka anggap perlu ketimbang berdiskusi untuk mengetahui apa yang diinginkan pasien. Hal ini merupakan efek negatif dari hospitalisasi. Berdasarkan prinsip pelaksanaan terapi lingkungan, autonomi diberikan sesuai perkembangan pasien. Pasien dalam kondisi psikotik berat, tindakan perlindungan diperlukan untuk mengontrol prilaku destruktif. Menunjukkan sikap respek dengan mendengarkan keinginan dan memenuhi kebutuhan merupakan langkah awal penerapan prinsip-prinsip autonomi. Dukungan perawat sangat diperlukan dalam menyediakan lingkungan yang aman, nyaman, penuh dukungan dan dapat diprediksi untuk meminimalkan perasaan cemas dan putus asa. Secara bertahap perawat terus mengurangi dukungan dan bantuan untuk memberi kesempatan pasien mengambil tanggung jawab terhadap proses perawatan dan pengobatannya. Pada tahap ini rencana aktivitas harian harus dibuat secara terstruktur dan berkelanjutan dengan melibatkan pasien. Ketika pasien sudah mampu menjalankan tanggung jawab peningkatan keterampilan sosial dan keterampilan hidup dapat diberikan sebagai bekal pasien kembali ke masyarakat. Hubungan terapeutik perawat dan pasien harus dilandasi sikap penerimaan dan saling percaya untuk meningkatkan harga diri dan kepercayaan diri pasien. Validasi setiap tindakan yang diberikan harus selalu dilakukan untuk menjamin bahwa tindakan perawatan dan pengobatan memberi makna positif bagi pasien sehingga meminimalkan kekambuhan dan memperbaiki 
prognosis penyakit. Tujuan yang ketiga yang disampaikan perawat dalam wawancara kelompok fokus adalah meningkatkan kerjasama dengan keluarga pasien. Terapi lingkungan memandang individu sebagai bagian dari sistem yang lebih besar, sehingga ketika pasien mengalami gangguan jiwa, maka akan mempengaruhi keluarga (Olkowska og Landmark, 2009). Keluarga merupakan elemen sosial yang paling dekat dan berpengaruh bagi kehidupan pasien. Keberadaan keluarga bisa menjadi sumber dukungan atau stresor. Pengetahuan dan pemahaman keluarga dapat menjadi sumber dukungan yang efektif bagi pasien dalam berjuang melawan penyakitnya. Namun stigma sering menjadi penghalang keluarga dalam merawat pasien di rumah. Keluarga sering menganggap pasien sebagai individu yang berbahaya sehingga sering tidak dilibatkan dalam aktivitas rumah tangga. Keluarga takut kalau pasien capek atau stres bisa menyebabkan kekambuhan atau mencelakai anggota keluarga yang lain. Padahal sebaliknya, kekambuhan sering diakibatkan oleh lingkungan keluarga yang monoton, kaku dan ambivalen. Hummelvoll, (2008) mengatakan bahwa keluarga memerlukan pelatihan, informasi, keterampilan komunikasi, dan dukungan emosional untuk dapat mendukung pasien. Pasien dengan gangguan jiwa kadang menunjukkan sikap penolakan. Pasien butuh waktu untuk menyendiri dan tidak mau melakukan kontak dengan orang lain. Keluarga harus memahami dan mengevaluasi setiap fenomena muncul. Keluarga harus memberi peluang pasien menunjukkan eksistensinya, bukan bersikap reaktif. Begitu juga ketika pasien sukar memahami keinginan keluarga, susah diatur dan suka marah-marah, harus dilihat sebagai akibat dari penyakit yang dialami. Menanggapi kelemahan perilaku pasien dengan sikap reaktif dapat meningkatkan tekanan psikologis yang pemicu kekambuhan. Keluarga harus mampu membaca dan memahami perilaku yang ditunjukkan pasien. Bila perilaku psikotik meningkat dan tidak terkontrol, maka keluarga harus merujuk pasien ke layanan kesehatan jiwa. Helsedirektoratet, (2008) mengatakan bahwa ada beberapa peran keluarga dalam menghadapi pasien dengan gangguan jiwa, yaitu sebagai sumber pengetahuan, pemberi perawatan, sumber dukungan, konsultan, dan penyedia kebutuhan. Tujuan perawat yang keempat adalah meningkatkan kerjasama lintas profesi. Kerjasama lintas profesi sangat penting dalam upaya peningkatan kualitas pelayanan. Peningkatan koordinasi dan sinergitas dalam pelayanan berkontribusi positif bagi perkembangan pasien. Semua profesi memiliki visi dan misi yang sama yaitu meningkatkan kesehatan jiwa pasien. Namun kenyataannya, kerjasam lintas profesi sering berjalan sendiri, kurang koordinasi, dan saling menonjolkan diri. Menurut perawat hal ini disebabkan oleh tingginya ego sektoral masing-masing profesi. Merasa diri paling penting dan paling dibutuhkan sehingga harus mendapat penghargaan dan imbalan jasa yang lebih besar sering menjadi pemicu kecemburuan dan ketidakadilan. Hummelvoll (2008) mengatakan 
bahwa syarat awal meningkatkan kerjasama lintas profesi adalah meningkatnya hubungan personal. Setiap petugas harus saling mengenal satu sama lain dan saling memahami tugas dan tanggung masing-masing. Hubungan baik antar individu menjadi jalan awal terbinanya hubungan antar profesi. Sosialisasi tugas dan tanggung jawab profesi juga penting dalam mengembangkan sikap saling menghargai dan saling menghormati. Tujuan kelima yang disampaikan perawat dalam wawancara kelompok fokus adalah memperbaiki praktek pelayanan. Perawat berkeinginan menggabungkan model MPKP dengan terapi lingkungan sebagai model baru pelayanan kesehatan jiwa dalam meningkatkan kualitas pelayanan. Perawat menginginkan penanganan pasien tidak hanya fokus pada mengatasi gejala saja, tapi penyediaan lingkungan yang aman, nyaman, variatif, penuh dukungan dan tidak monoton, dan bisa diprediksi juga penting untuk memberi kesempatan pasien menstabilisasi diri, mengembangkan pengetahuan, wawasan dan tanggung jawab sehingga meningkatkan potensi diri pasien dalam menghadapi penyakit dan permasalah kehidupan yang dihadapi. Perawat mengharapkan pihak manajemen memberikan peluang pengembangan praktek sesuai kreativitas ruang rawat. Pembatasan akan menghambat ideide kreatif perawat dalam pengembangan praktek. Pihak manajemen harus memberikan dukungan moril maupun materil dalam upaya pengembangan praktek berkelanjutan. Pengembangan Sumber
Daya Manusia (SDM) melalui pelatihan dan pendidikan dapat menjadi langkah awal yang sangatlah penting dalam upaya pengembangan praktek pelayanan. Untuk menjamin standarisasi pelayanan, penyusunan Standar Operasional Presedur (SOP) mutlak diperlukan. SOP akan menjadi panduan setiap perawat dalam melaksanakan asuhan keperawatan. SOP juga akan mengikat setiap perawat melaksanakan tindakan sesuai dengan visi dan misi rumah sakit. Namun untuk meningkatkan komitmen perawat dalam melaksanakan standarisasi layanan yang telah ditetapkan, sistem reward and punishment harus diberlakukan. Sistem reward and punishment diharapkan dapat meningkatkan motivasi perawat dalam melaksanakan dan mengembangkan praktek pelayanan berkelanjutan. Pengembangan terapi lingkungan Tujuan yang diperoleh dari hasil penelitian ini dapat dijadikan langkah awal dalam pengembangan terapi lingkungan. Penellitian lanjutan perlu dilakukan untuk menggali pengetahuan lokal tentang bagaimana mengembangkan wawasan dan pengetahuan pasien, bagaimana meningkatkan kemandirian pasien, bagaimana meningkatkan kerjasama dengan keluarga dan profesi yang pada akhirnya dapat memperbaiki kualitas pelayanan. Hal inilah yang dinginkan dari penelitian yang berbasis cooperative inquiry, dimana pengembangan layanan dilakukan berdasarkan local knowledge dengan memperhatikan budaya dan kearifan lokal. Dalam pengembangan terapi lingkungan, hubungan antara petugas 
dengan pasien menjadi fokus utama (Nysveen et al., 2008). Hubungan ini dapat dibentuk melalui pertemuan dan komunikasi. Dalam komunikasi seorang perawat berusaha mengidentifikasi dan memahami masalah pasien. Perawat harus dapat membentuk sebuah arena yang memiliki efek terapi guna meningkatkan ketrampilan dan pengetahuan sosial pasien. Hummelvoll, (2008) mengatakan bahwa aktivitas yang kreativ yang memberi kesempatan pasien bermain dengan ide dan pola pikir baru dalam memahami situasi, dan mampu menyerap informasi dari aktivitas yang dilakukan, seperti aktivitas musik, kerajinan tangan, pertanian, perkebuanan, serta aktivitas kelompok lainnya sangat dibutuhkan. Menurut tiori salutogenesa, terapi lingkungan lebih difokuskan pada perspektiv pemecahan masalah dari pada perspektiv penyakit (Almvik, og Borge, 2006). Autonomi pasien memiliki peran sentral dalam terapi lingkungan. Pasien diberi kesempatan mengambil keputusan terhadap tindakan perawatan dan pengobatan, sedangkan perawat hanya bertindak sebagai konsultan. Komunikasi dalam terapi lingkungan merupakan alat penting mengidentifikasi konflik yang mendasari gangguan jiwa. Dalam komunikasi seorang perawat harus muncul sebagai penolong untuk meringankan beban pasien. Perawat harus hadir secara nyata dan dekat dengan pasien, sehingga pertemuan dan komunikasi dirasakan bermakna oleh pasien. Dalam implementasikan terapi lingkungan, kita membutuhkan sebuah lingkungan yang terstruktur dan dapat memberik kepastian kepada pasien. Oleh karena itu rencana harian, mingguan dan bulanan diperlukan dalam perawatan dan pengobatan. Rencana keperawatan yang terstruktur dapat memberikan kepastian pada pasien, sehingga mereka merasa aman berada di ruang rawat. Selain itu, untuk meningkatkan kemandirian dan tanggung jawab pasien terhadap tindakan perawatan, maka perawat harus melibatkan pasien dalam rencana perawatan. Keterlihatan pasien akan meningkatkan pemahaman dan kerjasama pasien dalam menjalani perawatan dan pengobatan, sehingga pencapaian tujuan perawatan bukan hanya tanggung jawab perawat, tapi merupakan tanggung jawab pasien. Akhirnya perawat memvalidasi setiap tindakan yang dilakukan, apakah memiliki makna bagi positif bagi pasien.

\section{PENUTUP}

Kesimpulan

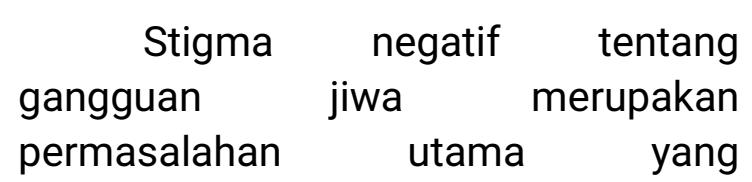
melatarbelakangi ide perencanaan dan perancangan balai kesehatan jiwa tersebut. Stigma negatif yang sudah melekat pada persepsi setiap orang memiliki dampak negatif bagi orang lain bahkan dirinya sendiri. Stigma negatif bahwa gangguan jiwa akan menyebabkan orang bertindak kekerasan, tidak dapat disembuhkan dan menjadi aib bagi seseorang telah menjadi masalah serius ditengahtengah masyarakat. Adanya stigma negatif ini diperburuk dengan perilaku 
dari masyarakat yang seolah-olah membenarkan stigma tersebut. Akibatnya, banyak kasus pemasungan, stres, halusinasi, dan kasus kesehatan jiwa lainnya yang semakin parah akibat penanganan yang terlambat atau kurang tepat karena kurangnya pengetahuan dan wawasan masyarakat.

Saran

Perlunya Penyuluhan kepada masyarakat Tentang gangguan jiwa bahwa orang yang mengalami gangguan jiwa tersebut harus di rehabilitasi bukan di jauhkan dan di biarkan oleh masyarakat, dan kepada pemerintah sebaiknya semua orang yang telah menggalami gangguan jiwa di rehabalititasi agar mereka yang telah mengalami gangguan jiwa tidak di biarkan berada di sekeliling masyarakt yang sedang beraktivitas, karena ada kemungkinan orang telah gangguan ke jiwaan akan menganggung dan mengancap masyarakat di sekitarnya

\section{DAFTAR PUSTAKA}

1. Aiyub, Puji Astuti. (2016). TUJUAN YANG DIGUNAKAN DALAM PELAYANAN KESEHATAN JIWA DI RUMAH SAKIT JIWA BANDA ACEH The Goals achieved by Nurses in Mental Health Care Delivery in Banda Aceh Mental Hospital. Idea Nursing Journal. Vol. VII No. 3 2016. 4-8

2. Azizah, Lilik Ma'rifatul. Dkk,. (2016). Buku Ajar Keperawatan Kesehatan Jiwa-Teori dan Aplikasi Praktik Klinik.
Yogyakarta: Indomedia Pustaka, 2016

3. Deva Bagus Zhafran, Hardiyati, Leny Pramesti. (2017). BALAl KESEHATAN JIWA DENGAN PENDEKATAN HEALING ENVIRONMENT DI SURAKARTA. Arsitektura, Vol. 15, No.1, April 2017: 149-155.

4. Dr. Heni Setyowati ER., M.Kes, (2018) Manajemen Penanganan Post Traumatic Stress Dissorder (PTSD). Magelang. UNIMMA PRESS

5. Monica Bendetu. (2015). Pendidikan Keperawatan Jiwa. Yogyakarta. Perpustakaan Nasional : Katalog Dalam Terbitan (KDT)

6. Rohmah, N., \& Walid, S. (2016). Proses Keperawatan : Teori \& Aplikasi. Jogjakarta : Ar-Ruzz Media.

7. Rosdahl, C. B., \& Kowalski, M. T. (2014). Buku Ajar Keperawatan Dasar. Jakarta : EGC

8. Safitri, R. (2019, September 27). Berfikir Kritis Menurut Para Ahli dan Penerapannya dalam Proses Keperawatan. Osf. io.

9. Simamora, R. H. (2009). Dokumentasi Proses Keperawatan.

10. Simamora, R. H., Purba. J M., Bukit, E. K., \& Nurbaiti, N. (2019) Penguatan Peran Perawat Dalam Melaksanakan Asuhan Keperawatan Melalui Pelatihan Layanan Prima. JPPM (Jurnal 
Pengabdian Dan Pemberdayaan Masyarakat). 3(1),25-31.

11. Unimus Repository,2012.

Proses Asuhan Dalam Keperawatan

12. Yanti, R., I., \& Warsito, B., E. (2013). Hubungan Karakteristik Perawat, Motivasi, dan Supervisi dengan Kualitas Dokumentasi Proses Asuhan Keperawatan. Jurnal Manajemen Keperawatan. 1 (2), 107-109. 